\title{
Association analysis between variants in KISS1 gene and litter size in goats
}

Xiaopeng An, Teng Ma, Jinxing Hou, Fang Fang, Peng Han, Yan Yan, Haibo Zhao, Yunxuan Song, Jiangang Wang and Binyun Cao*

\begin{abstract}
Background: Kisspeptins are the peptide products of KISS1 gene, which operate via the G - protein-coupled receptor GPR54. These peptides have emerged as essential upstream regulators of neurons secreting gonadotropin-releasing hormone $(\mathrm{GnRH})$, the major hypothalamic node for the stimulatory control of the hypothalamic-pituitary- gonadal (HPG) axis. The present study detected the polymorphisms of caprine KISSI gene in three goat breeds and investigated the associations between these genetic markers and litter size.

Results: Three goat breeds ( $n=680$ ) were used to detect single nucleotide polymorphisms (SNPs) in the coding regions with their intron-exon boundaries and the proximal flanking regions of KISS1 gene by DNA sequencing and PCR-RFLP. Eleven novel SNPs (g.384G>A, g.1147T>C, g.1417G>A, g.1428_1429delG, g.2124C>T, g.2270C>T, g.2489T>C, g.2510G>A, g.2540C>T, g.3864_3865delCA and g.3885_3886insACCCC) were identified. It was shown that Xinong Saanen and Guanzhong goat breeds were in Hardy-Weinberg disequilibrium at g.384G>A locus $(P<0.05)$. Both 9.2510G $>$ A and g.2540C $>$ T loci were closely linked in Xinong Saanen (SN), Guanzhong (GZ) and Boer (BG) goat breeds $\left(r^{2}>0.33\right)$. The g.384G $>A, g .2489 T>C, g .2510 G>A$ and g.2540C $>$ T SNPs were associated with litter size $(P<0.05)$. Individuals with AATTAATT combinative genotype of SN breed (SC) and TTAATT combinative genotype of BG breed (BC) had higher litter size than those with other combinative genotypes in average parity. The results extend the spectrum of genetic variation of the caprine KISS1 gene, which might contribute to goat genetic resources and breeding.

Conclusions: This study explored the genetic polymorphism of KISS1 gene, and indicated that four SNPs may play an important role in litter size. Their genetic mechanism of reproduction in goat breeds should be further investigated. The female goats with SC1 (AATTAATT) and BC7 (TTAATT) had higher litter size than those with other combinative genotypes in average parity and could be used for the development of new breeds of prolific goats. Further research on a large number of animals is required to confirm the link with increased prolificacy in goats.
\end{abstract}

Keywords: Combinative genotype, SNP, PCR-RFLP, Candidate gene

\section{Background}

Kisspeptins are the peptide products of KISS1 gene, which operate via the G - protein-coupled receptor GPR54 (also known as KISS1R). These peptides have emerged as essential upstream regulators of neurons secreting gonadotropinreleasing hormone (GnRH), the major hypothalamic node for the stimulatory control of the hypothalamic-pituitarygonadal (HPG) axis [1]. They are potent elicitors of gonadotropin secretion in various species and physiological settings. Moreover, KISS1 neurons in the hypothalamus

\footnotetext{
* Correspondence: caobinyun@126.com

College of Animal Science and Technology, Northwest A\&F University, Yangling, Shaanxi 712100, P.R. China
}

(c) 2013 An et al.; licensee BioMed Central Ltd. This is an Open Access article distributed under the terms of the Creative Commons Attribution License (http://creativecommons.org/licenses/by/2.0), which permits unrestricted use, distribution, and reproduction in any medium, provided the original work is properly cited.

participate in crucial features of reproductive maturation and function, such as brain-level sex differentiation, puberty onset and the neuroendocrine regulation of gonadotropin secretion and ovulation [2]. Irwig et al. (2004) and Navarro et al. (2004) have provided evidences in rats that kisspeptin-expressing neurons are targets for regulation by sex steroids [3,4], furthermore, these neurons are directly regulated by the negative and positive feedback actions of sex steroids in distinct regions of the forebrain [5].

Mutations of KISS1R are associated with hypogonadotrophic hypogonadism in humans [6,7], a phenotype which is also observed in mice carrying inactivating mutations of KISS1 or KISS1R genes [8]. In addition, to their prominent expression at hypothalamic levels, fragmentary 
evidences suggest that KISS1 and/or KISS1R mRNAs or proteins are also present in several peripheral reproductive tissues including the ovary $[9,10]$, oviduct $[11]$ and testes [12]. In humans, Pinto et al. (2012) reported kisspeptin modulated sperm progressive motility causing a biphasic (stimulatory and inhibitory) response and also induced transient sperm hyperactivation [13]. One novel nonsynonymous single nucleotide polymorphism (G54650055T) substituting one amino acid in kisspeptin (P110T) was found to be statistically related to central precocious puberty $(P<0.025)$ in humans [14]. In sheep, KISS1 mRNAexpressing cells are found in the arcuate nucleus (ARC) and dorsallateral preoptic area and both appear to mediate the positive feedback effect of estradiol to generate the preovulatory GnRH/LH surge [15]. The LH surge has been associated with an increase in the LH response to kisspeptin in humans and sheep [16,17], indicating the surge may be generated by increased kisspeptin output and sensitivity. These findings indicate that KISS1 gene is an excellent candidate gene for reproductive traits in human and livestock.

Based on above considerations, here we detected the polymorphisms of caprine KISS1 gene in three goat breeds and investigated the associations between these genetic markers and litter size. This study provides some useful information on goat genetic resources and breeding.

\section{Results}

\section{SNPs identification and genotypes}

In the current study, sequencing of the amplicons of different primer pairs identified eleven polymorphic nucleotide sites in caprine KISS1 gene. The g.384G>A mutation was in the 5'UTR (Additional file 1: Table S1), which was not found in BG breed. The g.3864_3865delCA and g.3885_3886insACCCC mutations were in the 3'UTR. Other mutations were in the intron 1 (g.1147T>C, g.141 7G>A, g.1428_1429delG, g.2124C>T, g.2270C > T, g.2489 T $>$ C, g.2510G $>$ A and g.2540C $>$ T). SNP accession number is showed in Additional file 1: Table S1. Four SNPs (g.384G >A, g.2489T >C, g.2510G >A and g.2540C > T) were genotyped in three goat breeds (Figures 1, 2, 3, and 4). At g.384G $>A$ locus, the PIC was 0.37 in $\mathrm{SN}$ and GZ breeds (Additional file 1: Table S2). At g.2489T $>C$ locus, the PIC was $0.24-0.29$ in three goat breeds. At other two loci, the PIC was $0.36-0.38$ in three goat breeds. Genotypic distribution and allelic frequencies of four SNPs are shown in Additional file 1: Table S2. It was shown that SN and GZ breeds were in Hardy-Weinberg disequilibrium at g.384G $>A$ locus $(P<0.05)$ (Additional file 1 : Table S2). To reveal the linkage relationships between the four SNPs, the linkage disequilibrium was estimated in these breeds (Additional file 1: Table S3). If $r^{2}>0.33$, the linkage disequilibrium was considered strong [18]. Following the

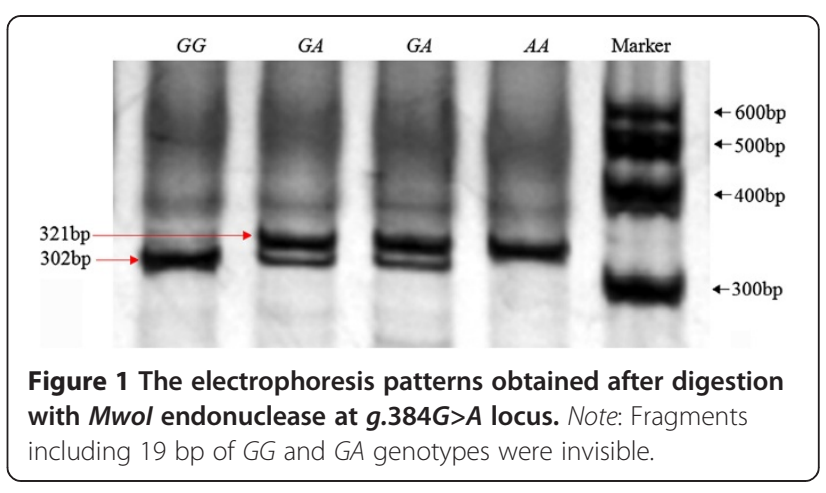

result, both $g .2510 G>A$ and $g .2540 C>T$ loci were closely linked in three goat breeds (Additional file 1: Table S3).

\section{Association analysis of SNPs with litter size}

At g.384G $>A$ locus in $\mathrm{SN}$ breed (Table 1), individuals with $A A$ genotype had greater litter size than those with $G G$ genotype in the second, third and average parity $(P<0.05)$; in GZ breed, individuals with $A A$ genotype had greater litter size than those with $G G$ genotype in the third and average parity $(P<0.05)$, and individuals with $G A$ genotype had greater litter size than those with $G G$ genotype in the first and average parity $(P<0.05)$. At $g .2510 G>A$ locus in $\mathrm{SN}$ breed (Table 2), individuals with $A A$ genotype had greater litter size than those with $G A$ genotype in the third parity $(P<0.05)$; in BG breed, individuals with $A A$ genotype had greater litter size than those with GG genotype in the fourth and average parity $(P<0.05)$. At

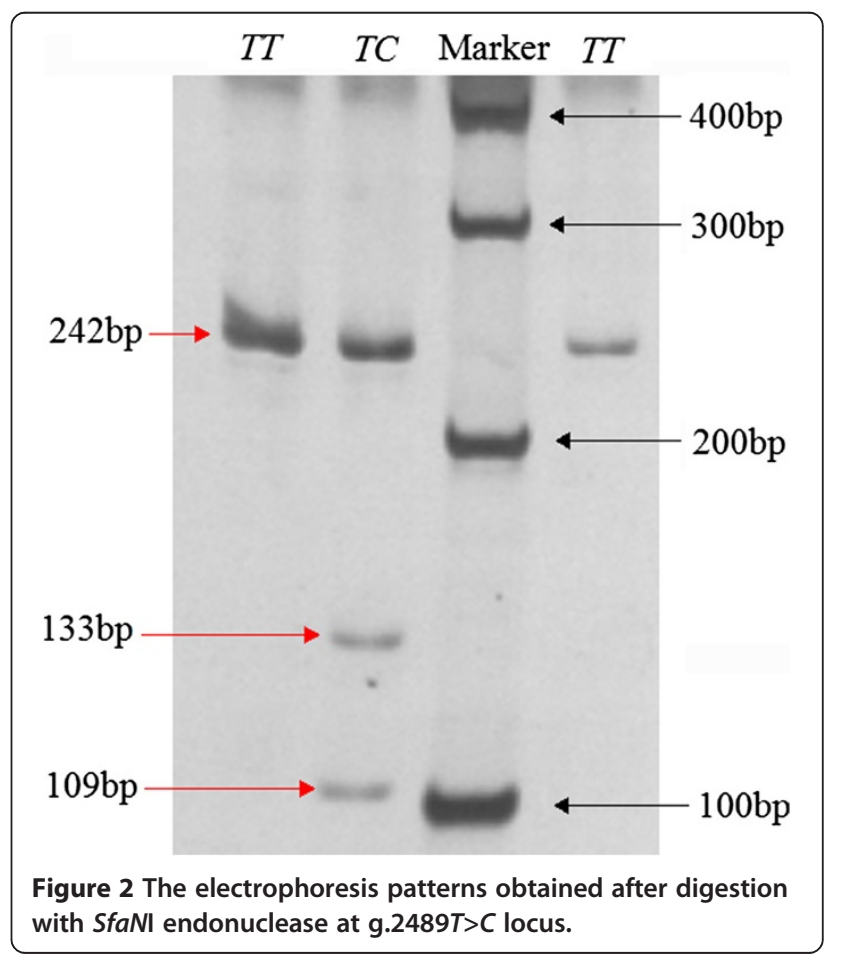




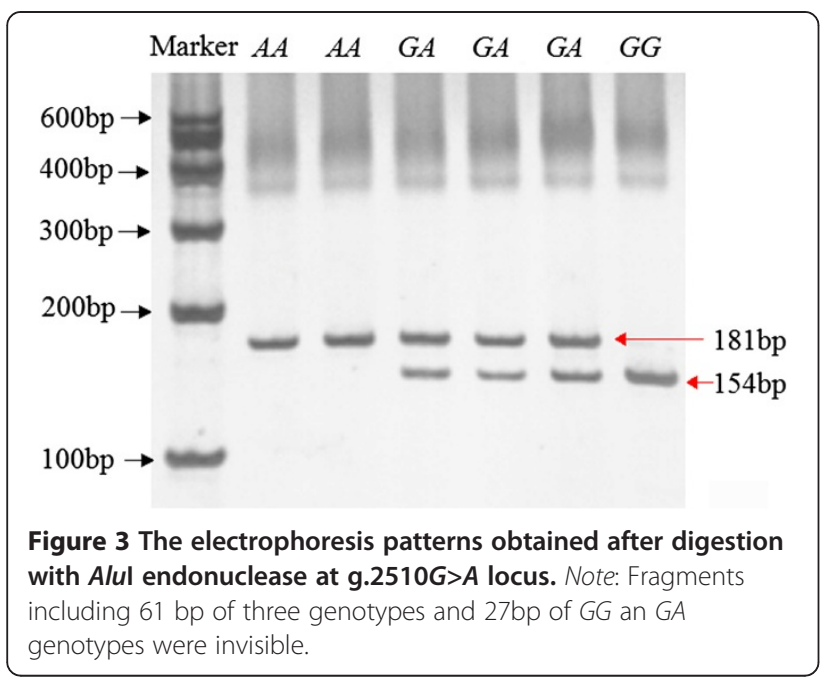

g.2540C $>T$ locus in GZ breed (Table 2), individuals with $T T$ genotype had greater litter size than those with $C C$ genotype in the fourth parity $(P<0.05)$; in BG breed, individuals with $T T$ genotype had greater litter size than those with $C C$ and $C T$ genotypes in average parity $(P<0.05)$.

\section{Effects of combinative genotypes on litter size}

Association analysis of combinative genotypes of $g .38$ $4 G>A, g .2489 T>C, g .2510 G>A$ and $g .2540 C>T$ loci with litter size was done in SN and GZ breeds. In SN breed (Additional file 1: Table S4), individuals with SC3 (AATCGACT) had the greatest litter size in comparison with other combinative genotypes in the first parity. Individuals with SC1 (AATTAATT) and SC3 (AATCGACT) had greater litter size than those with SC4 (AATTGACT) and SC10 (GGTTAATT) in the second parity $(P<0.05)$. Individuals with SC1 (AATTAATT) had greater litter size than those with SC2 (AATTGGCC) and SC4 (AATTGACT) in the fourth parity $(P<0.05)$. Individuals with SC3 (AATCGACT) had greater litter size than those with SC4 (AATTGACT), SC5 (GATCGGCC) and SC13 $($ GATTGGCC) in average parity $(P<0.05)$. In $\mathrm{GZ}$ breed (Additional file 1: Table S5), Individuals with GC2 (GATCGGCC) had greater litter size than those with GC12 (GGTCGACT) and GC14 (GGTCGATT) in the first parity $(P<0.05)$. Individuals with GC14 (GGTCGATT)

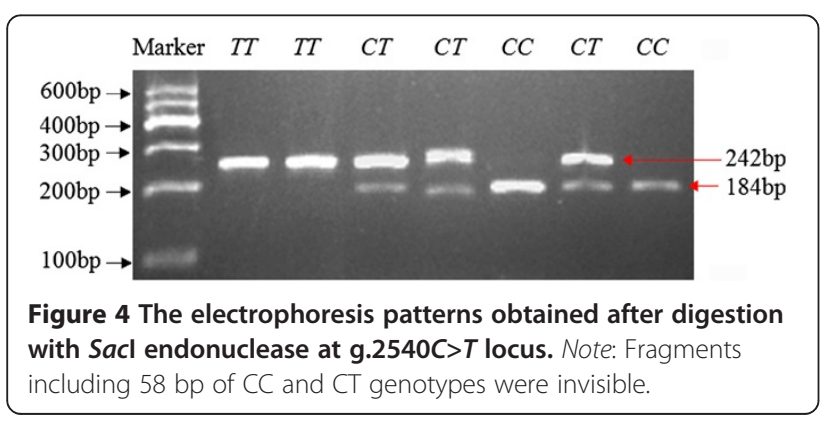

had the lowest litter size in comparison with other combinative genotypes in the third parity. Association analysis of combinative genotypes of g.2489T>C, g.2510G $>A$ and g.2540C $>T$ loci with litter size was done in BG breeds. In BG breed (Additional file 1: Table S6), individuals with BC7(TTAATT) had greater litter size than those with BC6 $(T T G A C T)$ in the third, fourth and average parity $(P<0.05)$. Individuals with BC6 (TTGACT) had the lowest litter size in comparison with other combinative genotypes in average parity.

\section{Discussion}

According to the classification of PIC (low polymorphism if PIC value $<0.25$, moderate polymorphism if $0.25<$ PIC value $<0.50$, and high polymorphism if $\mathrm{PIC}>0.50$ ), SN and GZ breeds at g.384G $>A$ locus had moderate genetic diversity, and SN, GZ and BG breeds had also moderate genetic diversity at g.2510G $>A$ and $g .2540 C>T$ loci. The g.384G $>A$ locus was in Hardy-Weinberg disequilibrium in $\mathrm{SN}$ and GZ breeds $(P<0.05)$, which showed the genotypic frequencies were affected by selection, mutation or migration.

Identification of the candidate genes that are responsible for variation in continuous traits or quantitative traits has been a challenge in modern genetics. So far, there have been some studies of KISS1 gene as a candidate gene on reproductive traits in animals, which revealed that KISS1 gene plays an important role in animal reproduction [18-21]. Both c.374C $>\mathrm{T}$ and c.422C $>\mathrm{G} \mathrm{mu-}$ tations were identified in human KISS1 gene, and the c. $374 \mathrm{C}>\mathrm{T}$ variant was associated with higher kisspeptin resistance to degradation in comparison with the wild type, suggesting a role for this mutation in the precocious puberty phenotype [22]. Huijbregts et al. (2012) detected three SNPs (c.638insT, c.641C $>\mathrm{G}$ and c.645G>CA) in the 3'UTR of human KISS1 gene, and the c.645G>CA mutation was associated with central precocious puberty [20]. In Jining Grey goat KISS1 gene, there are two mutations (G3433A and C3688A) in exon 3, three mutations (G296C, G454T and T505A) in intron 1 and an 18 bp deletion/insertion (1960-1977) in intron 2 and no mutations in exon 2 [23]. Feng et al. (2009) detected the polymorphism in exon 2 of goat KISS1 gene and did not find polymorphism [24]. In the current study, ten polymorphisms were detected in KISS1 gene of three goat breeds (g.1147T>C, g.1417G >A, g.1428_1429delG, g.2124C >T, g.2270C > T, g.2489T>C, g.2510G >A, g.2540C >T, g.3864_3 865delCA and g.3885_3886insACCCC). The g.384G>A mutation was detected in SN and GZ breeds. Cao et al. (2010) indicated an association between allele $C$ of the 296 locus and allele deletion of the 1960-1977 locus in KISS1 gene and high litter size in Jining Grey goats [23]. Hou et al. (2011) identified T2643C and 8bp base deletions (2677AGTTCCCC) in the intron 2 of goat KISS1 
Table 1 Least square means and standard errors of the litter size of SN and GZ breeds at $\mathbf{g . 3 8 4 G}>$ A locus

\begin{tabular}{|c|c|c|c|c|c|c|c|c|}
\hline Locus & Breed & Genotype & Number & $\begin{array}{l}1^{\text {st }} \text { parity litter } \\
\text { size }\end{array}$ & $\begin{array}{l}2^{\text {nd }} \text { parity litter } \\
\text { size }\end{array}$ & $\begin{array}{l}3^{\text {rd }} \text { parity litter } \\
\text { size }\end{array}$ & $\begin{array}{l}4^{\text {th }} \text { parity litter } \\
\text { size }\end{array}$ & $\begin{array}{l}\text { Average litter } \\
\text { size }\end{array}$ \\
\hline \multirow[t]{6}{*}{ g.384G>A } & SN & $A A$ & 44 & $1.57 \pm 0.09$ & $2.02 \pm 0.08^{b}$ & $2.22 \pm 0.09^{b}$ & $2.21 \pm 0.10$ & $2.00 \pm 0.05^{b}$ \\
\hline & & $G A$ & 144 & $1.44 \pm 0.05$ & $1.97 \pm 0.05^{b}$ & $2.03 \pm 0.06$ & $2.19 \pm 0.07$ & $1.91 \pm 0.03$ \\
\hline & & GG & 69 & $1.48 \pm 0.07$ & $1.79 \pm 0.07^{\mathrm{a}}$ & $1.98 \pm 0.07^{\mathrm{a}}$ & $2.21 \pm 0.08$ & $1.86 \pm 0.04^{\mathrm{a}}$ \\
\hline & $\mathrm{GZ}$ & $A A$ & 34 & $1.46 \pm 0.09$ & $1.62 \pm 0.09$ & $2.00 \pm 0.09^{b}$ & $1.94 \pm 0.09$ & $1.75 \pm 0.04^{b}$ \\
\hline & & $G A$ & 130 & $1.48 \pm 0.05^{b}$ & $1.65 \pm 0.04$ & $1.77 \pm 0.05^{\mathrm{a}}$ & $1.94 \pm 0.05$ & $1.71 \pm 0.02^{b}$ \\
\hline & & GG & 67 & $1.33 \pm 0.06^{\mathrm{a}}$ & $1.61 \pm 0.06$ & $1.70 \pm 0.07^{\mathrm{a}}$ & $1.91 \pm 0.07$ & $1.63 \pm 0.03^{a}$ \\
\hline
\end{tabular}

Note: Values with different superscripts within the same column in particular breed differ significantly at $P<0.05$.

gene and the T2643C had significant effects on litter size $(P<0.05)[25]$.

The reproductive traits are complex quantitative traits involving multiple genes, loci and interactions, so it is important to analyze the combined effect of multiple genes or loci on reproductive traits. In the study, association between multiple locus and litter size from the first to the fourth parity was analyzed. Mean litter size of goat tended to increase in later parity. Individuals with SC1 (AATTAATT) had higher litter size than those with SC4 (AATTGACT) and SC10 (GGTTAATT) in the second parity of $\mathrm{SN}$ breed. In addition, individuals with SC1 (AATTAATT) had higher litter size than those with SC10 (GGTTAATT) in average parity of SN breed. The litter size at second kidding is often a valuable index to determine whether a goat is prolific [26]. Therefore, SC1

Table 2 Least square means and standard errors of the litter size of three breeds at $g .2489 T>C, g .2510 G>A$ and g.2540C $>T$ loci

\begin{tabular}{|c|c|c|c|c|c|c|c|c|}
\hline Locus & Breed & Genotype & Number & $\begin{array}{l}1^{\text {st }} \text { parity litter } \\
\text { size }\end{array}$ & $\begin{array}{l}2^{\text {nd }} \text { parity litter } \\
\text { size }\end{array}$ & $\begin{array}{l}3^{\text {rd }} \text { parity litter } \\
\text { size }\end{array}$ & $\begin{array}{l}4^{\text {th }} \text { parity litter } \\
\text { size }\end{array}$ & $\begin{array}{l}\text { Average litter } \\
\text { size }\end{array}$ \\
\hline \multirow[t]{6}{*}{ g.2489T>C } & SN & $T C$ & 92 & $1.51 \pm 0.06$ & $1.95 \pm 0.06$ & $2.04 \pm 0.07$ & $2.21 \pm 0.07$ & $1.94 \pm 0.04$ \\
\hline & & $T T$ & 165 & $1.45 \pm 0.05$ & $1.92 \pm 0.05$ & $2.05 \pm 0.05$ & $2.19 \pm 0.06$ & $1.90 \pm 0.03$ \\
\hline & $\mathrm{GZ}$ & $T C$ & 105 & $1.36 \pm 0.05^{\mathrm{a}}$ & $1.68 \pm 0.05$ & $1.80 \pm 0.06$ & $1.89 \pm 0.06$ & $1.69 \pm 0.03$ \\
\hline & & TT & 126 & $1.50 \pm 0.05^{b}$ & $1.60 \pm 0.05$ & $1.78 \pm 0.06$ & $1.97 \pm 0.05$ & $1.70 \pm 0.02$ \\
\hline & $B G$ & $T C$ & 65 & $1.32 \pm 0.06$ & $1.78 \pm 0.07$ & $1.84 \pm 0.07$ & $1.98 \pm 0.07$ & $1.72 \pm 0.04$ \\
\hline & & TT & 127 & $1.29 \pm 0.05$ & $1.73 \pm 0.05$ & $1.87 \pm 0.06$ & $2.09 \pm 0.06$ & $1.72 \pm 0.03$ \\
\hline \multirow[t]{9}{*}{ g. $2510 G>A$} & SN & $A A$ & 95 & $1.49 \pm 0.06$ & $1.91 \pm 0.06$ & $2.12 \pm 0.07^{b}$ & $2.27 \pm 0.08$ & $1.94 \pm 0.04$ \\
\hline & & GA & 130 & $1.47 \pm 0.05$ & $1.95 \pm 0.05$ & $1.96 \pm 0.06^{a}$ & $2.15 \pm 0.07$ & $1.88 \pm 0.31$ \\
\hline & & $G G$ & 32 & $1.44 \pm 0.10$ & $1.93 \pm 0.09$ & $2.1 \pm 0.11$ & $2.17 \pm 0.12$ & $1.95 \pm 0.06$ \\
\hline & $\mathrm{GZ}$ & $A A$ & 55 & $1.52 \pm 0.07^{b}$ & $1.54 \pm 0.07$ & $1.69 \pm 0.08$ & $1.97 \pm 0.07$ & $1.68 \pm 0.04$ \\
\hline & & $G A$ & 118 & $1.36 \pm 0.05^{\mathrm{a}}$ & $1.67 \pm 0.05$ & $1.84 \pm 0.06$ & $1.94 \pm 0.05$ & $1.70 \pm 0.02$ \\
\hline & & GG & 58 & $1.51 \pm 0.07$ & $1.65 \pm 0.05$ & $1.79 \pm 0.07$ & $1.88 \pm 0.07$ & $1.71 \pm 0.03$ \\
\hline & $B G$ & $A A$ & 71 & $1.37 \pm 0.06$ & $1.79 \pm 0.06$ & $2.01 \pm 0.07^{b}$ & $2.20 \pm 0.07^{b}$ & $1.82 \pm 0.03^{b}$ \\
\hline & & GA & 89 & $1.24 \pm 0.05$ & $1.73 \pm 0.06$ & $1.75 \pm 0.06^{\mathrm{a}}$ & $1.97 \pm 0.06^{\mathrm{a}}$ & $1.65 \pm 0.03^{\mathrm{a}}$ \\
\hline & & $G G$ & 32 & $1.35 \pm 0.09$ & $1.73 \pm 0.09$ & $1.87 \pm 0.10$ & $1.87 \pm 0.09^{a}$ & $1.69 \pm 0.05^{a}$ \\
\hline \multirow[t]{9}{*}{$g .2540 C>T$} & SN & $C C$ & 42 & $1.43 \pm 0.09$ & $1.87 \pm 0.08$ & $2.00 \pm 0.10$ & $2.18 \pm 0.11$ & $1.90 \pm 0.05$ \\
\hline & & $C T$ & 121 & $1.52 \pm 0.05$ & $1.96 \pm 0.05$ & $1.99 \pm 0.06$ & $2.17 \pm 0.07$ & $1.93 \pm 0.03$ \\
\hline & & TT & 94 & $1.42 \pm 0.06$ & $1.94 \pm 0.06$ & $2.00 \pm 0.07$ & $2.24 \pm 0.08$ & $1.90 \pm 0.04$ \\
\hline & $G Z$ & $C C$ & 47 & $1.52 \pm 0.08$ & $1.68 \pm 0.07$ & $1.69 \pm 0.08$ & $1.78 \pm 0.08^{a}$ & $1.67 \pm 0.04$ \\
\hline & & $C T$ & 108 & $1.38 \pm 0.05$ & $1.62 \pm 0.05$ & $1.86 \pm 0.06$ & $1.94 \pm 0.05$ & $1.69 \pm 0.03$ \\
\hline & & TT & 76 & $1.46 \pm 0.06$ & $1.63 \pm 0.06$ & $1.77 \pm 0.07$ & $2.00 \pm 0.06^{b}$ & $1.71 \pm 0.03$ \\
\hline & $B G$ & $C C$ & 40 & $1.30 \pm 0.08$ & $1.71 \pm 0.09$ & $1.85 \pm 0.09$ & $2.01 \pm 0.09$ & $1.69 \pm 0.05^{\mathrm{a}}$ \\
\hline & & $C T$ & 89 & $1.25 \pm 0.05$ & $1.76 \pm 0.06$ & $1.78 \pm 0.06^{\mathrm{a}}$ & $1.98 \pm 0.06^{\mathrm{a}}$ & $1.67 \pm 0.03^{a}$ \\
\hline & & $T T$ & 63 & $1.38 \pm 0.06$ & $1.75 \pm 0.07$ & $2.00 \pm 0.07^{b}$ & $2.19 \pm 0.08^{b}$ & $1.81 \pm 0.04^{b}$ \\
\hline
\end{tabular}

Note: Values with different superscripts within the same column and mutation locus in particular breed differ significantly at $P<0.05$. 
(AATTAATT) can be used in marker-assisted selection to select the individuals with higher litter size. Accumulating evidence further showed that central or peripheral administration of kisspeptin stimulates GnRH-dependent luteinizing hormone (LH) and follicle-stimulating hormone (FSH) secretion in various mammalian species from rodents to humans [27-29], suggesting that kisspeptin plays an essential role in governing reproductive functions throughout species. The biochemical and physiological functions, together with the results obtained in our study, indicate that KISS1 gene could be as a molecular breeding marker in goats.

\section{Conclusions}

This study explored the genetic polymorphism of KISS1 gene, and indicated that four SNPs may play an important role in litter size. Their genetic mechanism of reproduction in goat breeds should be further investigated. The female goats with $\mathrm{SC} 1(A A T T A A T T)$ and $\mathrm{BC} 7$ (TTAATT) had higher litter size than those with other combination genotypes in average parity and could be used for the development of new breeds of prolific goats. Further research on a large number of animals is required to confirm the link with increased prolificacy in goats.

\section{Methods}

\section{Animals and genomic DNA isolation}

Blood samples were obtained from 680 goats belonging to three breeds: Xinong Saanen goat ( $\mathrm{SN} ; n=257)$, Guanzhong goat (GZ, $n=231$ ) and Boer goat (BG; $n=192)$. They were reared in Qianyang, Zhouzhi and Liuyou county of Shaanxi province, respectively. All diets were based on alfalfa, corn silage, and a combination of concentrates including corn, soya meal, and bone meal. Health, fertility and production records were maintained by the dairymen and veterinarians. The litter size from the first to fourth parity was obtained from production records. Five milliliters blood per goat were collected aseptically from the jugular vein and kept in a tube containing anticoagulant ACD (citric acid:sodium citrate: dextrose - 10: 27: 38). All samples were delivered back to the laboratory in an ice box. The genomic DNA was extracted from white blood cells using standard phenol-chloroform extraction protocol. All experiments were performed in accordance with the National Institute of Health Guide for the Care and Use of Laboratory Animals.

\section{SNPs investigation and genotyping}

According to caprine KISS1 gene (GenBank accession no. GU142847), Seven pairs of primers were designed to amplify caprine KISS1 gene. Their optimal annealing temperatures are showed in Additional file 1: Table S7. Herein we screened them for identifying SNPs of this gene by DNA pooling sequencing assay [30]. Five microliters DNA $(100 \mathrm{ng} / \mu \mathrm{l})$ per sample were collected to create a DNA pool for each goat breed. PCR products were sent to Beijing Genomics Institute (Beijing, China) to sequence in both directions. Discovery of SNPs was conducted using Chromas 2.31 and DNAstar 7.0 software.

The SNP in 5'UTR (89-409bp) of KISS1 gene was genotyped using primer-introduced restriction analysispolymerase chain reaction (PIRA-PCR) [31]. Other SNPs of KISS1 gene were genotyped with polymerase chain reaction-restriction fragment length polymorphism (PCRRFLP). The $25 \mu \mathrm{L}$ volume contained $50 \mathrm{ng}$ genomic DNA, $12.5 \mu \mathrm{L} 2 \times$ reaction mix (including $500 \mu \mathrm{M}$ dNTP each; 20 mM Tris-HCl; pH 9; 100 mM KCl; 3 mM $\mathrm{MgCl} 2$ ), $0.5 \mu \mathrm{M}$ of each primer, and 0.5 units of Taq DNA polymerase. The cycling protocol was $5 \mathrm{~min}$ at $95^{\circ} \mathrm{C}, 35$ cycles of denaturing at $94^{\circ} \mathrm{C}$ for $30 \mathrm{~s}$, annealing at $\mathrm{X}^{\circ} \mathrm{C}$ (Additional file 1: Table S7) for $30 \mathrm{~s}$, extending at $72^{\circ} \mathrm{C}$ for $35 \mathrm{~s}$, with a final extension at $72^{\circ} \mathrm{C}$ for $10 \mathrm{~min}$. PCR products $(5 \mu \mathrm{l})$ of different primer pairs were mixed with $0.7 \mu \mathrm{l} 10 \times$ Buffer, $2.5 \mathrm{U}$ restriction enzyme (NEB, Ipswich, Britain) and $3.8 \mu \mathrm{l}$ sterilized $\mathrm{dd}_{2} \mathrm{O}$, and then incubated for $1.5 \mathrm{~h}$ at $37^{\circ} \mathrm{C}$. The restriction enzymes were showed in Additional file 1: Table S1. Digestion products were subjected to $3.5 \%$ horizontal agarose gel electrophoresis or $12 \%$ polyacrylamide gel electrophoresis (PAGE). The agarose and polyacrylamide gels were stained with ethidium bromide and $0.1 \%$ silver nitrate, respectively, and then the genotypes were observed.

The allelic frequencies, heterozygosity $(\mathrm{He})$ and polymorphism information content (PIC) were calculated using Popgene (version 1.31). The linkage disequilibrium was performed by SHEsis software [19]. Association analysis of combinative genotypes of different loci in KISS1 gene with litter size was done in three goat breeds. $\mathrm{SC}_{\mathrm{n}}$, $\mathrm{GC}_{\mathrm{n}}$ and $\mathrm{BC}_{\mathrm{n}}$ represented different combinative genotypes of SN, GZ and BG breeds, respectively. Statistical analysis was performed using univariate analysis in the general linear model procedure of SPSS 16 statistical software. Multiple comparisons of the means were performed using the least significant difference method or Dunnett's T3. The model applied was: $Y_{\mathrm{ikm}}=\mu+G_{\mathrm{i}}+$ $S_{\mathrm{k}}+E_{\mathrm{ikm}}$, where $Y_{\mathrm{ikm}}$ is the trait measured on each of the $\mathrm{ikm}^{\text {th }}$ animal, $\mu$ is the overall population mean, $G_{\mathrm{i}}$ is the fixed effect associated with $i^{\text {th }}$ genotype or combinative genotype, $S_{\mathrm{k}}$ is the fixed effect associated with the $\mathrm{k}^{\text {th }}$ sire, and $E_{\mathrm{ikm}}$ is the random error. Effects associated with farm, birth year and season of birth are not matched in the linear model, as the preliminary statistical analyses indicated that these effects did not have a significant influence on variability of traits in the analyzed populations. 


\section{Additional file}

Additional file 1: Table S1. Identified SNPS within the KISS1 gene and positions in reference sequence. Table S2. Genotypic distribution and allelic frequencies of four SNP loci in KISS1 gene. Table S3. Linkage disequilibrium $\left(r^{2}\right)$ between four SNPs in KISS1 gene. Table S4. Least square means and standard errors of the litter size of SN breed for four locus genotypes in KISS1 gene. Table S5. Least square means and standard errors of the litter size of GZ breed for four locus genotypes in KISS1 gene. Table S6. Least square means and standard errors of the litter size of BG breed for g.2489T>C, g.2510G $>A$ and g.2540C $>T$ locus genotypes. Table S7. Primer sequences for goat KISS1 gene applied for screening polymorphisms and genotyping.

\section{Competing interests}

The authors declare that they have no competing interests.

\section{Authors' contributions}

$\mathrm{XA}, \mathrm{JH}$ and TM conducted all experiments and wrote the manuscript. FF, YY and $\mathrm{HZ}$ carried out the computational analysis. $\mathrm{PH}$ and $\mathrm{YS}$ contributed their ideas towards writing. BCao and JW conducted the research design. All authors read and approved the final manuscript.

\section{Acknowledgements}

This study was supported by the National Support Program of China (2011BAD28B05-3) and Science and Technology Innovation Project of Shaanxi Province (2011KTCL02-09).

Received: 5 December 2012 Accepted: 25 July 2013

Published: 2 August 2013

\section{References}

1. Navarro VM, Tena-Sempere M: Neuroendocrine control by kisspeptins: role in metabolic regulation of fertility. Nat Rev Endocrinol 2012, 8:40-53.

2. Caraty A, Franceschini I, Hoffman GE: Kisspeptin and the preovulatory gonadotrophin-releasing hormone/luteinising hormone surge in the ewe: basic aspects and potential applications in the control of ovulation. J Neuroendocrinol 2010, 22:710-715

3. Irwig MS, Fraleyb GS, Smith JT, Acohido BV, Popa SM, Cunningham MJ Gottsch ML, Clifton DK, Steiner RA: Kisspeptin activation of gonadotropin releasing hormone neurons and regulation of KiSS-1 mRNA in the male rat. Neuroendocrinology 2004, 80:264-272.

4. Navarro VM, Castellano JM, Fernandez-Fernandez R, Barreiro ML, Roa J, Sanchez-Criado JE, Aguilar E, Dieguez C, Pinilla L, Tena-Sempere M: Developmental and hormonally regulated messenger ribonucleic acid expression of KiSS-1 and its putative receptor, GPR54, in rat hypothalamus and potent luteinizing hormone-releasing activity of KiSS-1 peptide. Endocrinology 2004, 145:4565-4574.

5. Gottsch M, Clifton D, Steiner R: Kisspeptin-GPR54 signaling in the neuroendocrine reproductive axis. Biol Reprod 2006, 254-255:91-96.

6. de Roux N, Genin E, Carel JC, Matsuda F, Chaussain JL, Milgrom E: Hypogonadotropic hypogonadism due to loss of function of the KiSS1-derived peptide receptor GPR54. P Natl Acad Sci USA 2003, 100:10972-10976.

7. Seminara SB, Messager S, Chatzidaki EE, Thresher RR, Acierno JS, Shagoury JK, Bo-Abbas Y, Kuohung W, Schwinof KM, Hendrick AG, et al: The GPR54 gene as a regulator of puberty. New Engl J Med 2003, 349:1614-U1618.

8. Tena-Sempere M: Roles of kisspeptins in the control of hypothalamicgonadotropic function: focus on sexual differentiation and puberty onset. Endocr Dev 2010, 17:52-62

9. Castellano JM, Gaytan M, Roa J, Vigo E, Navarro VM, Bellido C, Dieguez C, Aguilar E, Sanchez-Criado JE, Pellicer A, et al: Expression of KiSS-1 in rat ovary: Putative local regulator ovulation? Endocrinology 2006, 147:4852-4862.

10. Gaytan F, Gaytan M, Castellano JM, Romero M, Roa J, Aparicio B, Garrido N Sanchez-Criado JE, Millar RP, Pellicer A, et al: KiSS-1 in the mammalian ovary: distribution of kisspeptin in human and marmoset and alterations in KiSS-1 mRNA levels in a rat model of ovulatory dysfunction. Am J Physiol-Endoc M 2009, 296:E520-E531.

11. Gaytan M, Castellano JM, Roa J, Sanchez-Criado JE, Tena-Sempere M, Gaytan F: Expression of KiSS-1 in rat oviduct: possible involvement in prevention of ectopic implantation? Cell Tissue Res 2007, 329:571-579.
12. Ohtaki T, Shintani Y, Honda S, Matsumoto H, Hori A, Kanehashi K, Terao Y, Kumano S, Takatsu Y, Masuda Y, et al: Metastasis suppressor gene KiSS-1 encodes peptide ligand of a G-protein-coupled receptor. Nature 2001, 411:613-617.

13. Pinto FM, Cejudo-Roman A, Ravina CG, Fernandez-Sanchez M, MartinLozano D, Illanes M, Tena-Sempere M, Candenas ML: Characterization of the kisspeptin system in human spermatozoa. Int J Androl 2012, 35:63-73.

14. Luan XH, Zhou YX, Wang W, Yu H, Li P, Gan XH, Wei DZ, Xiao JH: Association study of the polymorphisms in the KISS1 gene with central precocious puberty in Chinese girls. Eur J Endocrinol 2007, 157:113-118.

15. Smith JT, Li Q, Yap KS, Shahab M, Roseweir AK, Millar RP, Clarke IJ: Kisspeptin is essential for the full preovulatory LH surge and stimulates $\mathrm{GnRH}$ release from the isolated ovine median eminence. Endocrinology 2011, 152:1001-1012.

16. Dhillo WS, Chaudhri OB, Thompson EL, Murphy KG, Patterson M, Ramachandran R, Nijher GK, Amber V, Kokkinos A, Donaldson M, et al: Kisspeptin-54 stimulates gonadotropin release most potently during the preovulatory phase of the menstrual cycle in women. $J$ Clin Endocr Metab 2007, 92:3958-3966.

17. Smith JT, Saleh SNH, Clarke IJ: Seasonal and cyclical change in the luteinizing hormone response to kisspeptin in the ewe. Neuroendocrinology 2009, 90:283-291.

18. Ardlie $K G$, Kruglyak $L$, Seielstad M: Patterns of linkage disequilibrium in the human genome. Nat Rev Genet 2002, 3:299-309.

19. Shi YY, He L: SHEsis, a powerful software platform for analyses of linkage disequilibrium, haplotype construction, and genetic association at polymorphism loci. Cell Res 2005, 15:97-98.

20. Huijbregts L, Roze C, Bonafe G, Houang M, Le Bouc Y, Carel JC, Leger J, Alberti P, de Roux N: DNA polymorphisms of the KiSS1 3 ' Untranslated region interfere with the folding of a G-rich sequence into G-quadruplex. Mol Cell Endocrinol 2012, 351:239-248.

21. Tomikawa J, Homma T, Tajima S, Shibata T, Inamoto Y, Takase K, Inoue N, Ohkura S, Uenoyama Y, Maeda K, et al: Molecular characterization and estrogen regulation of hypothalamic KISS1 gene in the pig. Biol Reprod 2010, 82:313-319.

22. Silveira LG, Noel SD, Silveira-Neto AP, Abreu AP, Brito VN, Santos MG, Bianco SDC, Kuohung W, Xu S, Gryngarten M, et al: Mutations of the KISS1 gene in disorders of puberty. J Clin Endocr Metab 2010, 95:2276-2280.

23. Cao GL, Chu MX, Fang L, Di R, Feng T, Li N: Analysis on DNA sequence of KiSS-1 gene and its association with litter size in goats. Mol Biol Rep 2010, 37:3921-3929.

24. Feng $T$, Zhao YZ, Chu MX, Zhang YJ, Fang L, Di R, Cao GL, Li N: Association between sexual precocity and alleles of KISS-1 and GPR54 genes in goats. Anim Biotechnol 2009, 20:172-176.

25. Hou JX, An XP, Wang JG, Song YX, Cui YH, Wang YF, Chen QJ, Cao BY: New genetic polymorphisms of KiSS-1 gene and their association with litter size in goats. Small Ruminant Res 2011, 96:106-110.

26. Yuqin W, Li YX, Zhang NN, Wang ZB, Bai JY: Polymorphism of exon 2 of BMP15 gene and its relationship with litter size of two Chinese goats. Asian Austral J Anim 2011, 24:905-911.

27. Gottsch ML, Cunningham MJ, Smith JT, Popa SM, Acohido BV, Crowley WF, Seminara S, Clifton DK, Steiner RA: A role for kisspeptins in the regulation of gonadotropin secretion in the mouse. Endocrinology 2004, 145:4073-4077.

28. Navarro VM, Castellano JM, Fernandez-Fernandez R, Tovar S, Roa J, Mayen A, Nogueiras R, Vazquez MJ, Barreiro ML, Magni P, et al: Characterization of the potent luteinizing hormone-releasing activity of KiSS-1 peptide, the natural ligand of GPR54. Endocrinology 2005, 146:156-163.

29. Shahab M, Mastronardi C, Seminara SB, Crowley WF, Ojeda SR, Plant TM: Increased hypothalamic GPR54 signaling: a potential mechanism for initiation of puberty in primates. Proc Natl Acad Sci USA 2005, 102:2129-2134.

30. Bansal A, van den Boom D, Kammerer S, Honisch C, Adam G, Cantor CR, Kleyn P, Braun A: Association testing by DNA pooling: an effective initial screen. Proc Natl Acad Sci USA 2002, 99:16871-16874.

31. Ke X, Collins A, Ye S: PIRA PCR designer for restriction analysis of single nucleotide polymorphisms. Bioinformatics 2001, 17:838-839.

doi:10.1186/1471-2156-14-63

Cite this article as: An et al:: Association analysis between variants in KISS1 gene and litter size in goats. BMC Genetics 2013 14:63. 